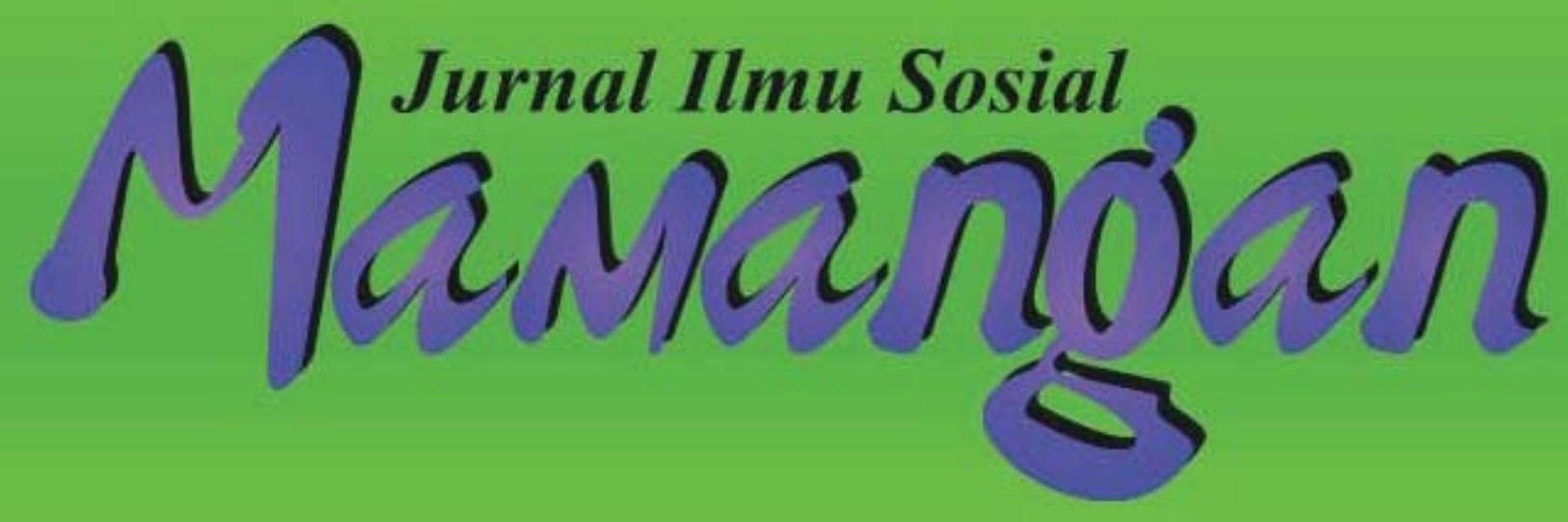

Beberapa Hipotesis Tentang Eksklusi Sosial di Indonesia Robert M.Z. Lawang

Dapatkah Indonesia Bebas Dari Kutukan Kolonial?

Refleksi Kritis Atas MP3EI

Noer Fauzi Rachman \& Dian Yanuardy

Rontoknya Dominasi Negara di Tambang Batu Bara Ombilin Sawahlunto

Zaiyardam Zubir \& Zulqayyim

Protes Korban Bencana; Studi Konflik Penanggulangan Bencana di Pasar Raya Padang

Firdaus

Peran Perempuan dalam Resolusi Konflik Rehabilitasi dan Rekonstruksi Pasar Raya Padang Ira Ariesta

Resolusi Konflik Berbasis Adat; Studi Resolusi Konflik Harta Pusaka Tinggi di Nagari Gantuang Ciri, Kab. Solok, Sumatera Barat

Yuhelna

Nelayan Vs Rentenir; Studi Ketergantungan Nelayan terhadap Rentenir pada Masyarakat Pesisir Delmira Syafrini 


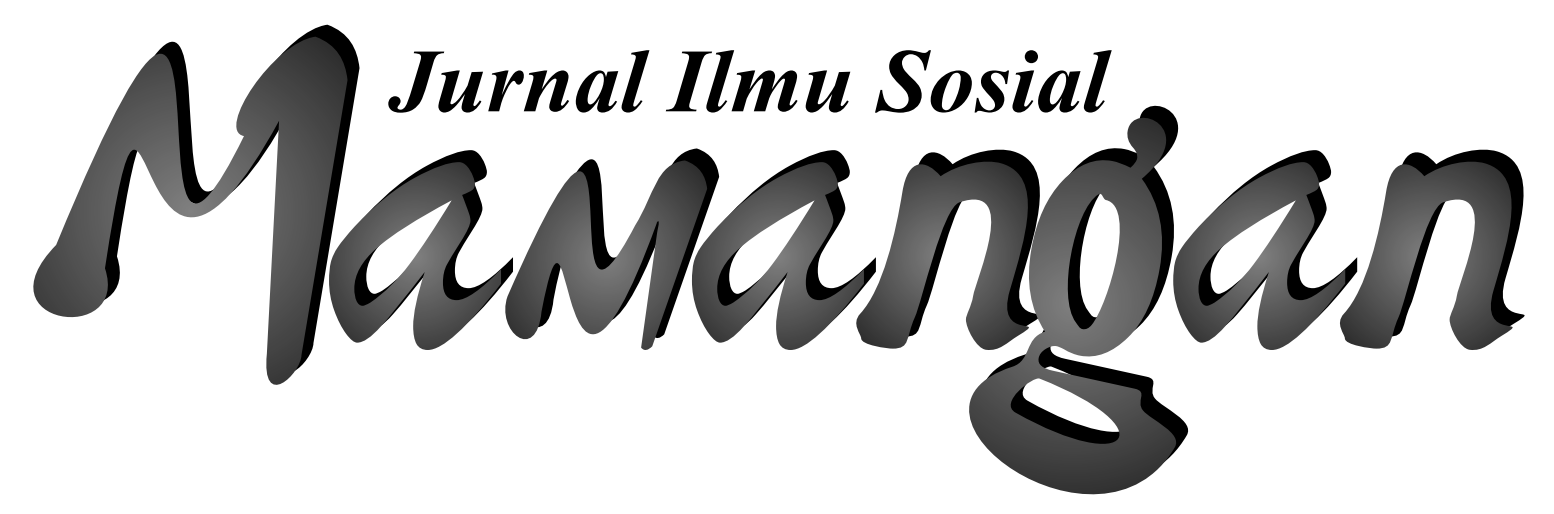




\section{Mitra Bestari}

Prof. Dr. Afrizal, MA. (FISIP, Unand Padang)

Prof. Dr. Badaruddin, M. Si. (FISIP, USU Medan)

Dr. A. Latief Wiyata, M. Si. (Universitas Jember, Jember)

Dr. Fikarwin Zuska, M. Si. (FISIP, USU Medan)

Nurus Shalihin, M. Si., Ph.D. (Fak. Ushuluddin IAIN Imam Bonjol Padang)

Dr. Semiarto A. Purwanto, M. Si. (FISIP, UI Jakarta)

Dr. Wahyu Wibowo, M. Si. (Universitas Nasional, Jakarta)

\section{Dewan Redaksi}

Dr. Zusmelia, M. Si.

Dr. Maihasni, M. Si.

Firdaus, S. Sos., M. Si.

\section{Pemimpin Redaksi/Editor}

Firdaus, S. Sos., M. Si.

\section{Anggota Redaksi}

Dian Kurnia Anggreta, S. Sos., M. Si.

Rinel Fitlayeni, S. Sos., MA.

Rio Tutri, M. Si

Sri Rahayu, M. Pd

Surya Prahara, SH,. MH.

Yuhelna, MA.

ISSN: 2301-8496

viii +81 halaman, $21 \times 29 \mathrm{~cm}$

\section{Alamat Redaksi:}

Laboratorium Program Studi Pendidikan Sosiologi, STKIP PGRI Sumbar Kampus STKIP PGRI, Jl. Gunung Pangilun, Padang, Sumatera Barat

Email: redaksimamangan@yahoo.com \& daus_gila@yahoo.com

\section{Penerbit:}

Laboratorium Program Studi Pendidikan Sosiologi, STKIP PGRI Sumbar

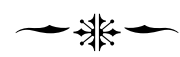




\section{PENGANTAR REDAKSI}

K onflik dalam masyarakat merupakan keniscayaan. Ia akan terus menjadi bagian dalam dinamika kemasyarakatan dan mengejawantah dalam berbagai bentuk yang secara garis bersar dikategorikan sebagai bentuk laten dan bentuk manifest. Pola dan bentuk konflik juga terus mengalami perkembangan sesuai dengan tingkat perkembangan masyarakat dimana konflik tersebut ada. Pola dan bentuk itu, mulai dari yang sederhana hingga yang paling 'canggih' dan bahkan disengaja ada untuk kepentingan tertentu oleh kelompok tertentu.

Meskipun para penganut fungsionalisme meganggap bahwa konflik dalam kehidupan sosial adalah abnormal (Johnson, 1994:161), namun konflik di lain kesempatan merupakan fakta sosial yang bisa fungsional bagi struktur tertentu selama ia dikelola dengan baik. Maka konflik kemudian di beberapa kesempatan juga dibutuhkan untuk kepentingan-kepentingan tertentu. Sehingga dengan demikian, adakalanya konflik mengikuti polanya sendiri dan adakalanya seirama dengan perkembangan masyarakat.

Menyadari bahwa perkembangan masyarakat terus melaju ke bentuk yang lebih kompleks, dan asumsi bahwa konflik juga akan kompleks sesuai dengan perkembangan kompleksitas masyarakat, Mamangan Edisi II yang ada di tangan pembaca ini mengambil konflik sebagai tema umum. Dalam edisi ini konflik dilihat oleh penulis dalam berbagai dimensi melalui berbagai pendekatan, baik secara teoritis maupun empiris melalui studi lapangan. Beberapa pakar di bisangnya telah menyumbang dalam dalam edisi kedua ini.

Tulisan pertama disumbangkan oleh Prof. Robert Lawang yang mendiskusikan konsep eksklusi sosial dalam konteks sosial, ekonomi dan politik. Tiga ranah ini menurut Lawang dikuasai arus utama (main stream) yang tidak mudah dimasuki oleh kelompok sosial tertentu dalam masyarakat paling bawah (underclass), sehingga mereka mengalami deprivasi. Selain itu, Lawang juga menyebut adanya perbedaan pandangan dan cara menjelaskan gejala sosial yang terkait eksklusi sosial. Meskipun konsep eksklusi sosial adalah konsep Barat, namun di Indonesia menurut Lawang, eksklusi sosial terjadi dalam berbagai struktur sosial masyarakat, baik di perkotaan maupun di pedesaan. 
Tulisan kedua disumbangkan oleh Noer Fauzi Rachman dan Dian Yanuardy yang mengupas secara kritis MP3EI. Dalam tulisannya, Fauzi dan Dian mempreteli skema MP3EI dan menyebutnya sebagai bagian dari upaya untuk memperdalam integrasi tanah air Indonesia ke dalam zona perdagangan bebas ASEAN dan Asia Timur. menurut mereka MP3EI pada pokoknya bertumpu pada upaya untuk melakukan reorganisasi ruang dalam rangka memperlancar interaksi dan aliran kapital, barang dan tenaga kerja untuk aktivitas produksi-konsumsi. Skema MP3EI dalam pola pemberian lisensi pada perusahaan untuk mengeksploitasi Sumber daya Alam menurutnya tidak jauh berbeda dengan kebijakan pemerintah kolonial Belanda sejak 1870, yang menempatkan Indonesia sebagai tempat produksi komoditas global.

Tulisan ketiga disumbangkan oleh Zayardam Zuber dan Zulqayim tentang rontoknya dominasi negara di Tambang Batubara Omblin, Sawahlunto. Zayardam dan Zulqayim dalam tulisannya mengemas sejarah beralihnya tambang di Kota Sawahlunto dari tangan perusahaan ke tangan rakyat yang selama puluhan tahun hanya menjadi penonton di arena tambang. Proses peralihan tersebut menurut Zayardan dan Zulqayim antara lain dilatari oleh penguasaan terhadap lahan di sekitar tambang yang dikuasi oleh dua kelompok, yaitu masyarakat adat dan pemerintah daerah. Selain itu, menurunnya aktivitas tambang PT. BA-UPO selaku BUMN yang kemudian menyerahkan pengurusan tambang kepada Pemda setempat juga menjadi bagian dari latar rontokya dominasi negara.

Tulisan keempat disumbangkan oleh Firdaus yang menguraikan protes korban bencana dalam proses rehabilitasi dan rekonstruksi di Pasar Raya Padang. Firdaus menyebutkan faktor penyebab munculnya protes adalah kebijakan pembangunan yang tidak partisipatif dan merugikan pedagang yang merupakan korban bencana. Kebijakan itu dibuat oleh pemerintah melalui mekanisme yang tidak sesuai dengan aturan yang ada. Protes yang dilakukan oleh korban bencana dilakukan dengan berbagai strategi, mulai dari strategi konfrontasi hingga negosiasi.

Tulisan kelima disumbangkan oleh Ira Ariesta yang mengulas peran perempuan dalam resolusi konflik Pasar Raya Padang. Ulasan Ira 'nyambung' dengan tulisan Firdaus sebelumnya. Jika Firdaus lebih menekankan pembahasan tentang penyebab dan strategi protes, maka Ira lebih menekankan pada resolusi konflik. Resolusi konflik yang dibahas Ira lebih fokus lagi pada peran perempuan. Menurut Ira, peran perempuan dalam proses resolusi konflik di Pasar Raya dilakukan oleh empat aktor utama, yaitu perempuan dari instansi pemerintah, perempuan aktivis LSM (PBHI Sumbar), perempuan aktivis mahasiswa dan perempuan pedagang. Keempat kelompok memainkan peran yang berbeda dalam resolusi konflik, mulai dari aksi massa hingga kegiatan advokasi terorganisir.

Tulisan keenam disumbangkan oleh Yuhelna yang membahas tentang mekanisme penyelesaian konflik harta pusaka tinggi secara adat di Minangkabau. Penyelesaian konflik harta pusaka tinggi di Minangkabau dilihat di nagari Gantuang Ciri. Resolusi konflik dilakukan pada 3 tingkatan. Tingkatan pertama resolusi konflik dilakukan di tingkat suku dengan melibatkan pangulu suku. Tingkat kedua resolusi konflik dilakukan pada tingkat yang lebih luas, yaitu pada institusi Tigo Niniak atau Ampek Niniak. Pada tingkat ini, resolusi konflik difasilitasi oleh niniak mamak masing-masing suku atau kaum yang berkonflik. Pada tingkat ketiga resolusi konflik dilakukan di lembaga adat Kerapatan Adat Nagari (KAN). Resolusi konflik pada tingkat ini difasilitasi oleh pengurus KAN yang merupakan perwakilan dari semua suku yang ada dalam nagari.

Tulisan terakhir, disumbangkan oleh Delmira Syafrini yang menganalisis ketergantungan nelayan dengan tengkulak di wilayah pesisir. Delmira melihat ketergantungan nelayan terhadap rentenir sebagai fenomena yang dilematis. Di satu sisi, nelayan mendapat kemudahan mengakses 
modal, di sisi lain nelayan dirugikan dengan suku bunga yang tinggi. Sementara, lembaga keuangan seperti Bank belum mampu menjadi katup penyelamat karena mekanisme rungguhan yang disyaratkan lembaga ini tidak terjangkau oleh nelayan. Di bagian akhir, Delmira menawarkan pemberdayaan sebagai solusi untuk memutus ketergantungan nelayan terhadap rentenir.

Demikianlah tulisan pada edisi ini, dan kepada para penyumbang tulisan pada edisi ini redaksi mengucapkan terima kasih atas karya intelektual dan buah pemikiran mereka, dan kepada para pembaca, redaksi mengucapkan selamat membaca. 



\section{DAFTAR ISI}

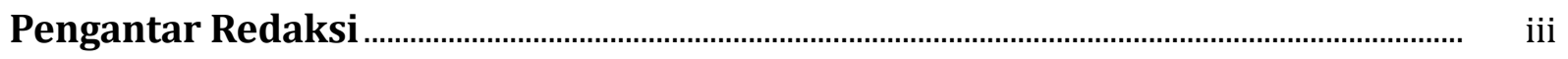

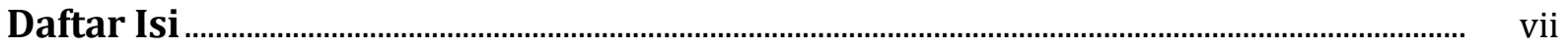

Beberapa Hipotesis Tentang Eksklusi Sosial di Indonesia

Robert M.Z. Lawang

Dapatkah Indonesia Bebas Dari Kutukan Kolonial?

Refleksi Kritis Atas MP3EI

Noer Fauzi Rachman \& Dian Yanuardy

Rontoknya Dominasi Negara di Tambang Batu Bara Ombilin Sawahlunto

Zaiyardam Zubir \& Zulqayyim

Protes Korban Bencana; Studi Konflik Penanggulangan Bencana di

Pasar Raya Padang

Firdaus

Peran Perempuan dalam Resolusi Konflik Rehabilitasi dan Rekonstruksi

Pasar Raya Padang

Ira Ariesta

Resolusi Konflik Berbasis Adat; Studi Resolusi Konflik Harta Pusaka Tinggi di Nagari Gantuang Ciri, Kab. Solok, Sumatera Barat

Yuhelna

Nelayan Vs Rentenir; Studi Ketergantungan Nelayan terhadap Rentenir pada Masyarakat Pesisir

Delmira Syafrini .

Profil Penulis. 



\title{
DAPATKAH INDONESIA BEBAS DARI KUTUKAN KOLONIAL? REFLEKSI KRITIS ATAS MP3EI ${ }^{1}$
}

\author{
Noer Fauzi Rachman \& Dian Yanuardy \\ (Kedua Penulis adalah Peneliti Sajogyo Institute Untuk Dokumentasi dan Studi Agraria Indonesia) \\ 一挑-
}

\begin{abstract}
This paper seeks to analyze critically the so-called Master Plan for the Acceleration and Expansion of Indonesian Economic Development (MP3EI)--- a newly development master plan launched in 2011 during Susilo Bambang Yudhoyono administration. MP3EI introduced some keywords such as "economic corridors", "Focused InvestmentZones", "connectivity", "infrastructure development", and so forth. This paper intends to unpack the origins and paradigm of MP3EI by tracing and analyzing "Comprehensive Asia Development Plan" (CADP)--- a document which was launched in 2009 by the Economic Research Institute for ASEAN and East Asia (ERIA). This paper shows that MP3EI is a framework and development design based on consesionary policy, infrastructure development projects as service links, and the dispersion of industrial zones in Indonesia. Finally, the writers argue that the current development model promoted by MP3EI is a colonial curse.
\end{abstract}

Kata Kunci:MP3EI, Infrastruktur, Geografi Ekonomi Baru, Krisis Sosial-Ekologis

\section{Pendahuluan}

Masterplan Percepatan dan Perluasan Pembangunan Ekonomi Indonesia (MP3EI) adalah suatu kerangka pembangunan yang mendasarkan pada asumsi bahwa pasar global adalah kesempatan emas. MP3EI adalah suatu kerangka pembangunan nasional yang

1. Dipetik dari laporan studi Sajogyo Institute (2014) "Proses-proses Kebijakan dan Konsekuensi dari Master Plan Percepatan dan Perluasan Ekonomi Indonesia (MP3EI)". Studi ini dikoordinasi oleh Dian Yanuardy, dengan anggota tim Didi Novrian, Muntaza, dan Swanvri, di bawah arahan peneliti utama Noer Fauzi Rachman, PhD dan Mia Siscawati PhD. Studi ini dijalankan dengan sebagian dukungan pendanaan berasal dari Samdhana Institute dan Climate and Land Use Alliance (CLUA). mempercayai bahwa Indonesia harus menyadari posisinya dalam pembagian kerja ekonomi internasional, dan mengoptimasikan posisinya sebagai produsen dan pengeksport komoditas global yang berbasiskan sumber daya alam. Konsekuensinya tidak dibicarakan bahwa pasar global bisa menjadi kekuatan pemaksa yang mampu mereorganisasi dan merekonstruksi ruang geografis pedesaan, untuk pembukaan ruang-ruang baru bagi situs-situs produksi komoditas global yang dimulai dengan mengubah hubungan kepemilikan rakyat pedesaan dengan tanah, kekayaan alam, dan wilayahnya, dan segala 
hal-ihwal kebudayaannya yang hidup di atasnya dan melekat secara sosial pada tempat-tempat itu sebelumnya.

Ellen M. Wood $(1994,2002)$ membedakan market-as-opportunity (pasar-sebagaikesempatan), dan market-as-imperative (pasarsebagai-paksaan). Pasar sebagai kesempatan bekerja melalui proses sirkulasi barang dagangan. Kebutuhan manusia pada gilirannya dibentuk agar dapat mengkonsumsi apa-apa yang diproduksi. Sebagai suatu sistem produksi yang khusus, ia mendominasi cara pertukaran komoditas melalui pasar. Lebih dari itu, perusahaan-perusahaan raksasa sanggup membentuk bagaimana cara sektor ekonomi dikelola oleh badan-badan pemerintahan hingga ke pemikiran bagaimana cara ekonomi pasar itu diagung-agungkan. Sementara itu, pasar-sebagai-keharusan dapat dipahami mulai dari karakter sistem produksi kapitalis sebagai yang paling mampu dalam mengakumulasikan keuntungan melalui kemajuan dan sofistikasi teknologi, serta peningkatan produktivitas tenaga kerja per-unit kerja, dan efisiensi hubungan sosial dan pembagian kerja produksi dan sirkulasi barang dagangan. Kesemuanya mengakibatkan penggantian pabrik-pabrik yang telah usang, sektor-sektor ekonomi yang tidak kompetitif, hingga keterampilan para pekerja yang tidak lagi dapat dipakai. Sebagai sistem produksi yang khusus, kapitalisme ini memberi tempat hidup dan insentif bagi semua komponen yang efisien, dan menghukum mati atau membiarkan mati hal-hal yang tidak sanggup menyesuaikan diri dengannya. Selanjutnya, di atas apa-apa yang telah dihancurleburkan itulah dibangun sesuatu yang baru, yang dapat lebih menjamin penciptaan keuntungan dan keberlangsungan akumulasi modal.

Naskah ini merupakan pandangan kritis atas dasar-dasar pemikiran yang mendasari MP3EI, karakeristik model pembangunan yang dinaungi MP3EI, refleksi mengenai posisi Indonesia dalam konteks globalisasi ekonomi dewasa ini, dan penutup yang berupa pandangan ke depan.

\section{Geografi Ekonomi Baru dan Pembentukan "Pabrik Asia"}

MP3EI merupakan bagian dari upaya untuk memperdalam integrasi tanah-air Indonesia ke dalam zona perdagangan bebas ASEAN dan Asia Timur. Dasar pemikiran utama dari model integrasi ekonomi untuk ASEAN dan Asia Timur ini bertumpu pada teori Geografi Ekonomi Baru (GEB) (Krugman, 1991; 2010), yang pada pokoknya bertumpu pada upaya untuk melakukan reorganisasi ruang dalam rangka memperlancar interaksi dan aliran kapital, barang dan tenaga kerja untuk aktivitas produksi-konsumsi.

GEB merupakan suatu cabang dalam pemikiran ekonomi ruang (spatial economy) yang berupaya untuk memaparkan pembentukan berbagai macam bentuk aglomerasi ekonomi dalam geografi ruang dengan menggunakan sudut pandang keunggulan komparatif geografi suatu lokasi atau negara (Schmutzler, 1999). Aglomerasi dengan pembuatan kluster-kluster ekonomi dapat terjadi di berbagai level geografi. Pada level global, aglomerasi dapat tampil seperti dalam terbentuknya struktur pusat-periferi (core-periphery). Kisaran sepuluh tahun lalu, NAFTA misalnya menyumbangkan 35\% dari PDB dunia, sementara Uni Eropa menyumbangkan 29\%, dan Asia Timur 23\%. Sebagian besar PDB dunia disumbangkan sebagai hasil dari pembentukan zona dan kluster ekonomi tersebut. Pada level regional, aglomerasi juga bisa tampak dari tumbuhnya kota-kota besar yang mendorong munculnya industri-industri skala kecil dan menengah di sekitarnya, yang kadangkala juga mendorong tumbuhnya industri dan teknologi yang berhubungan, sebagaimana terjadi di Silicon Valley, atau munculnya kota-kota industri seperti Toyota di Jepang dan Hershey di AS (Fujita dan Mori, 2005)

Model ekonomi aglomerasi pada intinya bertumpu pada upaya untuk menjelaskan bagaimana kondisi spatial equilibrium dapat terbentuk melalui adanya gerak sentrifugal yang dapat menarik aktivitas ekonomi secara bersamaan dengan gerak sentripetal yang dapat 
mendorong aktivitas semacam itu berpencar ke berbagai arah. Spatial equilibrium dapat terjadi dan bergantung pada adanya trade-off antara meningkatnya tingkat keuntungan di satu sisi dengan biaya mobilitas di sisi lain. Karena itu, teori ini menekankan pentingnya sebuah kondisi dimana tingkat pengembalian terhadap skala meningkat (increasing return to scale), biaya transportasi (transportation costs) yang rendah, dan adanya keterkaitan antara perusahaan, pemasok, dan konsumen (Schmutzler, 1999).

Kerangka pikir GEB ini utamanya digunakan oleh, World Development Report 2009 dari Bank Dunia, yang bertajuk "Reshaping Economic Geography". Laporan tersebut berupaya untuk menginvestigasi relasi antara pertumbuhan makro ekonomi dengan pembentukan-ulang geografi pada umumnya dan pembangunan regional. Laporan Bank Dunia memiliki konsep dasar bahwa reorganisasi dan penataan geografi yang tepat dapat meningkatkan efisiensi, mengurangi biaya produksi dan transaksi, serta meningkatkan pertumbuhan (Harvey 2009). Kerangka pikir GEB itu juga yang menjadi dasar bagi pemikiran MP3EI tentang pembentukan koridor ekonomi dan konektivitas. GEB ini juga yang menjadi rujukan dari Comprehensive Asia Developoment Plan (CADP) yang disusun oleh ERIA (Economic Research Institute for ASEAN and East Asia) pada tahun 2009. Orientasi CADP adalah untuk membuat Asia menjadi pabrik dunia, Untuk itu dirumuskan bahwa Asia memiliki dua tantangan besar: (i) tekanantekanan ekonomi di masa globalisasi memerlukan tingkatan integrasi ekonomi yang lebih tinggi dari sebelumnya; dan (ii) Asia terdiri dari negaranegara dan wilayah-wilayah yang memiliki perbedaan dalam tahapan pembanguna dengan keragaman latar belakang sejarah, budaya dan politik. CADP diniatkan untuk mengatasi dua tantangan itu (ERIA, 2009:vi)

Seluruh cerita rujukan induk pembangunan Asia dan Indonesia pada dasarnya diinspirasi dari praktik korporasi multinasional dalam menjalankan jaringan produksi internasional. Ilustrasi terbaik dalam hal ini adalah perusahaan otomotif asal Jepang atau industri elektronik Korea. Kerangka semacam inilah yang hendak digunakan dalam CADP melalui konsep penciptaan berbagai koridor ekonomi yang berisi upaya untuk pemencaran blok produksi (production block) dan pembangunan layanan penghubung (service link). Praktik jaringan produksi internasional dianggap sebagai jawaban saat ini, sebab Asia dengan praktik jaringan produksi internasionalnya saat ini dianggap menjadi pusat gravitasi ekonomi dunia. Dukungan utama dari model praktik jaringan produksi internasional semacam ini juga datang dari berbagai macam korporasi besar dari Amerika Serikat, Eropa, Asia, Australia dan lainnya. Semuanya dibungkus dalam mimpi menjadikan Asia, sebagai “Pabrik Asia”(Asian Factory).

Definisi Asian Factory adalah suatu model yang berisi jaringan-jaringan produksi tingkat regional yang menghubungkan pabrikpabrik di berbagai wilayah ekonomi Asia yang memproduksi bagian-bagian dan komponenkomponen yang kemudian dirakit, dan produk akhirnya dikirim ke wilayah-wilayah "ekonomi maju". Jaringan-jaringan tersebut merupakan bagian dari rantai produksi komoditas di tingkat regional dan global. "Dengan kata lain, saat ini East-Asia sejatinya sudah menjadi the factory of the world" (ERIA, 2009 :vi).

Jepang sejak tahun 1980, 1990 dan 2000 menduduki urutan kedua besar dari rangking pabrik dunia, dengan urutan pertamanya Amerika Utara. Tahun 1990an pabrik dunia masih didominasi Amerika Utara dan Eropa, dengan China mulai masuk menjadi kompetitor utama (urutan ke-7). Tahun 2000, Korea masuk ke rangking ke-8, China naik ke urutan ke-3. Mulai 2011 China naik ke urutan pertama, USA di posisi kedua, Jepang posisi ke-3, Korea ke-6, India ke-10, dan Indonesia ke-13. Sejak 2011, Factory Asia menjadi pusat produksi dunia. (Asian Development Bank, 2013: 6). 
Kehadiran MP3EI mempertegas pola pembangunan ekonomi dan industri Indonesia yang semakin berjalan ke arah melayani korporasi raksasa dan memfasilitasi pasar bekerja. Dalam kerangka semacam itu, rejim penguasa pemerintahan di bawah kepemimpinan Susilo Bambang Yudhoyono itu kemudian secara aktif mentransformasi cara pemerintah bekerja demi membuat MP3EI bekerja. Dalam konteks inilah, sungguh menarik untuk menyebut kalimat terakhir dari pidato Presiden Indonesia, Susilo Bambang Yudhoyono pada pertemuan Chief Executife Officer [CEO] APEC (Asia Pacific Economic Cooperation), Nusa Dua, Bali 6 Oktober 2013, yang mengibaratkan Indonesia sebagai perusahaan, dengan posisi dirinya sebagai "chief salesperson of Indonesia Inc."

Selain secara aktif mempromosikan MP3EI dan mendayagunakan struktur birokrasi pemerintah menjadi panitia pelaksana di tingkat nasional, propinsi, hingga kabuapten. Dalam kasus pembangunan infrastruktur, semakin terlihat bahwa infrastruktur memang telah bergeser fungsi, oleh siapa dia dilakukan, dan untuk apa dia dibuat. Jika dulu diasumsikan bahwa infratsruktur merupakan barang publik yang wajib disediakan oleh pemerintah untuk keselamatan dan kesejahteraan rakyat, maka kini infrastruktur adalah barang publik yang disediakan oleh negara maupun korporasi dan digunakan utamanya untuk kepentingan industri. Apalagi, pembangunan infrastruktur dilakukan dengan cara memangkas subsidi rakyat dan menambah hutang di satu sisi, dan memberi berbagai macam fasilitas dan insentif kepada para pengusaha di sisi lain.

\section{Konsesi Sumber Daya Alam, Kawasan Ekonomi, dan Infrastruktur}

Ada satu model pembangunan yang dinaungi oleh MP3EI yang mendasarkan diri pada tiga pilar utama, yaitu konsesi sumber daya alam skala luas, pembentukan zona industri, dan pembangunan proyek-proyek infrastruktur. Penguasaan dan pengelolaan sumber daya alam skala luas oleh perusahaan-perusahaan raksasa dimulai dengan pemberian lisensilinsesi terutama di sektor pertambangan, perkebunan, dan kehutanan, untuk memproduksi beragam komoditas global atau komoditas keperluan ekspor. Badan-badan pemerintah pusat dan daerah memberikan konsesi-konsesi yang berupa Hak Pengusahaan Hutan (HPH) dan Hak Pengusahaan Hutan untuk Tanaman Industri (HPHTI), yang merupakan dua bentuk konsesi kehutanan terutama untuk ekstraksi kayu. Sementara, untuk Konsesi Pertambangan bentuk ijin yang berupa Kontrak Karya (KK), Kuasa Pertambangan (KP), atau Izin Usaha Pertambangan bagi beroperasinya industri tambang skala besar. Sementara untuk usaha perkebunan, negara memberikan Hak Guna Usaha (HGU) atau Izin Usaha Perkebunan untuk berbagai macam usaha perkebunan.

Sesungguhnya, model pemberian lisensi sumber daya alam skala luas ini berakar pada kebijakan pemerintah kolonial Belanda sejak 1870, yang menempatkan Indonesia sebagai tempat produksi komoditas global (Fauzi, 1999). Pemerintah paska-kolonial melanjutkan kebijakan pemberian lisensi yang berujung pada konsesikonsesi penguasaan wilayah yang luas untuk ekstraksi barang tambang, kayu dan sumber daya alam lain, dan juga untuk produksi komoditaskomoditas perkebunan. Desain MP3EI bukan hanya melestarikan dan memperluas pemberian lisensi-lisensi skala besar untuk ekstraksi sumber daya alam dan produksi komoditas global tersebut, melainkan juga memperdalamnya melalui pembentukan kawasan-kawasan ekonomi khusus, termasuk dengan kebijakan pengolahan komoditas-komoditas yang dihasilkan oleh konsesi tersebut untuk masuk sebagai bahan mentah industri lain yang berada dalam satu wilayah penguasaan. Kebijakan ini disebut dalam dokumen MP3EI sebagai “hilirisasi." Pembentukan kawasan industri seperti ini pada dasarnya 
adalah pembentukan suatu zona pengecualian (zones of exception), yaitu sebuah ruang khusus dimana hukum-hukum dan norma-norma formal dikecualikan dan tidak diterapkan. Dalam kasus pembentukan kawasan industri demikian ini, pengecualian diberikan berupa berbagai macam fasilitas kelas satu untuk industri, keringanan pajak, kemungkinan mendapatkan pekerja asing yang dibayar mahal, pekerja lokal yang dibayar murah, dan fasilitas kemudahan untuk mendapatkan akses atas tanah untuk kawasan tersebut.

Sementara pembangunan infrastruktur dilakukan dengan tujuan untuk memperpendek jarak waktu untuk kelancaran lalu lintas barang, komoditas, uang dan tenaga kerja. Selain itu, ekonomi dunia kapitalis saat ini juga menempatkan infrastruktur sebagai bisnis. Infrastruktur telah bergeser dari layanan publik yang disediakan oleh pemerintah untuk keselamatan dan kesejahteraan rakyat menjadi suatu bisnis infrastruktur dari negara atau swasta yang utamanya ditujukan untuk kepentingan industri.

\section{Kontradiksi-Kontradiksi MP3EI}

Kerangka pembangunan MP3EI sebenarnya merupakan suatu upaya untuk memuluskan kepentingan investasi korporasi raksasa melalui dua mekanisme, yaitu "pembukaan ruang-ruang baru untuk industri" dan "penghilangan hambatan ruang yang ditempuh melalui pembangunan infrastruktur agar waktu untuk realisasi keuntungan semakin cepat". Kehadiran pembangunan kapitalis semacam selalu melahirkan kontradiksi. Ia melahirkan kemakmuran dan keberlimpahan di satu sisi, tetapi juga menciptakan pemiskinan dan kesengsaraan sosial-ekologis di sisi lain. Dalam setiap aliran kapital selalu terdapat berbagai kontradiksi, di antaranya: Pertama, sebagai syarat hidupnya, kapital beroperasi melalui dua transformasi, dimana "alat subsistensi sosial dan produksi diubah menjadi kapital, dan produsen langsung diubah menjadi tenaga kerja upahan"
(Marx 1976). Untuk mendirikan perkebunan skala besar, pabrik atau kawasan industri, para kapitalis dengan beragam cara harus dan mesti membuat orang terpisah dari tanah dan ruang hidupnya, baik melalui perampasan tanah secara langsung maupun melalui transaksi. Dan para kapitalis juga mesti mengubah nasib produsen langsung seperti petani, masyarakat adat, pengrajin skala kecil, untuk menjadi buruh upahan. Hanya dengan jalan inilah maka ketersediaan tanah dan tenaga kerja untuk kepentingan industri dapat terus-menerus tersedia. Inilah kontradiksi dan konsekuensi pertama ketika kapital bekerja.

Kedua, setiap proses produksi kapital selalu berkontradiksi dengan alam. Proses produksi kapital pasti bekerja dalam ruang hidup dan lingkungan tertentu. Para kapitalis bekerja dengan cara mengubah secara drastis ruang dan lingkungan tersebut. Ruang-ruang baru terbentuk dan relasi sosial baru atas ruang juga terbentuk. Untuk mendirikan perkebunan sawit, perusahaan tambang atau kawasan industri, misalnya, maka dibangunlah kompleks pabrik, perkebunan, pertambangan jaringan transportasi, komunikasi dengan cara mengubah hutan, laut, tanah, sungai, sumber air sedemikian rupa untuk kepentingannya. Di titik inilah sering terjadi kerusakan alam dan krisis ekologis lainnya.

Ketiga, setiap proses akumulasi kapital selalu menghadirkan kontradiksi lainnya, yaitu eksploitasi pekerja oleh pemilik kapital. Ini terjadi dalam semua proses akumulasi kapital. Cara bagaimana kapitalis memperoleh laba adalah dengan melakukan eksploitasi tenaga kerja. Seorang yang menjadi buruh hanya menjual tenaga kerjanya atau kemampuannya untuk bekerja dalam jangka waktu tertentu. Sementara, seorang kapitalis hanya membayarkan upah sejumlah nilai yang proporsional terhadap syarat-syarat produksinya, atau yang biasa disebut gaji. Jadi laba para kapitalis didapatkan dari selisih antara jumlah yang dibayarkan dengan kelebihan kerja buruh yang tak dibayarkan. Disini, eksploitasi berarti buruh mesti bekerja lebih banyak dari yang 
dibutuhkan untuk dirinya sendiri dan dari apa yang telah dibayarkan oleh para kapitalis.

Salah satu manifestasi yang paling laten dari pembangunan kapitalis semacam ini adalah konflik agraria. Penjelasan mengenai konflik agraria yang belum banyak diungkap adalah sebab-sebab struktural yang bersumber pada bagaimana pembangunan yang bercorak kapitalistik bekerja. Konflik agraria struktural yang dimaksud dalam hal ini merujuk pada pertentangan klaim yang berkepanjangan mengenai siapa yang berhak atas akses pada tanah, sumber daya alam (SDA), dan wilayah antara suatu kelompok rakyat pedesaan dengan badan penguasa/pengelola tanah yang bergerak dalam bidang produksi, ekstraksi, konservasi, dan lainnya; dan pihak-pihak yang bertentangan tersebut berupaya dan bertindak, secara langsung maupun tidak, menghilangkan klaim pihak lain.

Konflik agraria yang dimaksud dimulai oleh surat keputusan pejabat publik, termasuk Menteri Kehutanan, Menteri ESDM (Energi Dan Sumber Daya Mineral), Kepala BPN (Badan Pertanahan Nasional), Gubernur, dan Bupati, yang memberi ijin/hak/lisensi pada badan usaha tertentu, dengan memasukkan tanah, SDA, dan wilayah kepunyaan rakyat ke dalam konsesi-konsesi agraria yang bergerak dalam bidang ekstraksi, produksi, maupun konservasi berbasiskan sumberdaya alam.

Salah satu penanda dari bagaimana MP3EI memperdalam dan memperluas konflik agraria adalah semakin meluasnya konflik agraria. Data konflik agraria yang dikeluarkan oleh Konsorsium Pembaharuan Agraria (KPA), misalnya, menunjukkan bahwa jika dibandingkan tahun 2012 terdapat tren peningkatan kuantitas konflik agraria sebanyak 86,36\%. Sementara, terjadi kenaikan luas wilayah konflik sebesar 33,03\% antara tahun 2012 ke 2013. Apalagi, jika dilihat dari jenis konflik agraria yang muncul. Pada tahun 2013, konflik agraria yang dipicu oleh pembangunan infratsruktur menempati posisi kedua terbanyak setelah konflik agraria di wilayah perkebunan. (KPA, 2013, "Ini Data Konflik Agraria di Tanah Air Sepanjang 2013”, diakses dari http://www.kpa.or.id/?p=2947, 13 Juli 2013). Perkembangan ini menunjukkan bahwa pembangunan infrastruktur, yang merupakan salah satu skema pembangunan MP3EI telah melahirkan konflik agraria struktural.

\section{Keluar dari Kutukan Kolonial?}

Menurut penulis, pembangunan ekonomi Indonesia saat ini mengidap apa yang mungkin bisa disebut sebagai "tiga kutukan kolonial". Secara lantang, Ir. Soekarno, Presiden pertama Republik Indonesia, menyebut tiga kutukan kolonial itu, yakni, pertama, "Indonesia mendjadi pasar penjualan daripada produk-produk negeri pendjadjah atau negeri-negeri luaran di tanah air kita"; kedua, "Indonesia mendjadi tempat pengambilan bahan-bahan pokok bagi industriil kapitalisme di negeri pendjadjah atau negerinegeri lain", dan ketiga, "Indonesia mendjadi tempat investasi daripada modal-modal pendjadjah dan modal-modal asing jang lain". Pandangan ini disampaikan oleh Presiden Soekarno pada sidang pleno pertama Dewan Perantjang Nasional (1959) di Istana Negara, 28 Agustus 1959.

Kutukan kolonial itu, oleh Soekarno, dikontraskan dengan keperluan untuk secara leluasa "menyusun masyarakat Indonesia merdeka yang gagah, kuat, sehat, kekal dan abadi". Secara jelas hal ini dipidatokan oleh Ir. Soekarno di Badan Persiapan Usaha-usaha Kemerdekaan 1 Juni tahun 1945, setelah memaknai kemerdekaan Indonesia sebagai "jembatan emas". Betapa ironisnya bahwa Indonesia masih berkedudukan persis sama di tahun 2014, setelah enam puluh sembilan tahun berjalan melewati "jembatan emas" kemerdekaan. Indonesia seharusnya tidak lagi berkedudukan yang melanggengkan kedudukan Indonesia sebagai "Een natie van koelies enen koelie onder de naties", "A nation of coolies and a coolie amongst nations". 


\section{Pandangan ke Depan}

Kesempatan dan keberanian pejabat publik untuk menyatakan berhenti dari segala cara pembangunan yang mengancam keselamatan rakyat, merusak produktivitas rakyat, menghancurkan layanan alam, dan membuat kesejahteraan rakyat merosot. Sebaliknya, berbelok menempuh jalan baru bangsa ini, jalan yang mampu membalikkan situasi krisis sosial-ekologis itu, dan memulai usaha memulihkannya dari satuan-satuan yang paling dasar, yakni kampung-kampung, sekolahsekolah, sanggar-sanggar kebudayaan, kelompokkelompok studi lokal, kelompok-kelompok tani, komunitas-komunitas masyarakat adat, usahausaha ekonomi kecil, dan sebagainya, hingga satuan-satuan nasional, seperti partai politik, parlemen, senator, organisasi masyarakat sipil, universitas, dan sebagainya.

Pemerintah yang akan datang harus melakukan sebuah new deal, suatu model pembangunan yang mendayagunakan persatuan kekuatan Negaradan masyarakatuntukmenghadapi kesulitan-kesulitan untuk mewujudkan cita-cita masyarakat adil makmur. Dalam konteks sekarang, segenap komponen negara memerlukan kata kerja baru, yakni pemulihan kerusakan sosial-ekologis, yang komponen utamanya adalah memastikan keselamatan rakyat, meningkatkan produktivitas rakyat, mempemperbaiki layanan alam, dan meningkatkan kesejahteraan rakyat (Sangkoyo, 1999).

Soekarno menyatakan bahwa "kesulitankesulitan hendaknja tidak mendjadi penghalang daripada tekad kita, tidak mendjadi penghalang daripada kesediaan kita untuk terus berdjoang dan terus bekerdja, bahkan kesulitan-kesulitan itu hendaknja mendjadi satu tjambukan bagi kita untuk berdjalan terus, bekerdja terus oleh karena memang diharapkan daripada kita sekarang ini realisasi daripada penjelenggaraan daripada masjarakatjang adil dan makmur jang telah lama ditjita-tjitakan oleh rakjat Indonesia".
Pada sidang pleno pertama Dewan Perantjang Nasional (1959) di Istana Negara, 28 Agustus 1959, Soekarno menyatakan bahwa Indonesia harus "dengan tegas harus menuju kepada masjarakat adil dan makmur", yang pada waktu itu disebutnya sebagai "masyarakat sosialis ala Indonesia", dan upaya merealisasikannya "tidak boleh tidak kita harus mengadakan planning dan kita harus mengadakan pimpinan dan harus kita mengadakan kerahan tenaga." Ia menegaskan bahwa "Tanpa planning, tanpa pimpinan, tanpa pengerahan tenaga tak mungkin masyarakat yang dicita-citakan oleh rakyat Indonesia itu bisa tercapai dan terrealisasi".

Karena itu, pemimpin dalam semua satuan harus bekerja secara gotong-royong berpartisipasi dengan planning yang matang untuk menjalankan norma-norma dasar dari Undang-udang Dasar 1945. Negara Indonesia didirikan dan diatur oleh prinsip-prinsip dan norma-norma dan pengaturan dasar telah diletakkan dalam Konstitusi UUD 1945. Jadi, saat ini perlu untuk mendudukkan cita-cita pendirian negara sebagai pedoman dan mengembangkan suatu pandangan berdasarkan pada Konstitusi. Cita-cita pendirian bangsa itu perlu menjadi rujukan utama bagi pemerintah dalam memposisikan diri dan menjalankan perannya untuk "melindungi segenap bangsa Indonesia dan seluruh tumpah darah Indonesia dengan berdasar atas persatuan dengan mewujudkan keadilan sosial bagi seluruh rakyat Indonesia".

\section{Daftar Pustaka}

Fauzi, Noer. 1999. Petani dan Penguasa. Perjalanan Politik Agraria Indonesia. Yogyakarta: Pustaka Pelajar bekerjasama dengan Insist Press dan Konsorsium Pembaruan Agraria.

Fujita, Masahisa and Tomoya Mori. 2005. "Frontier of the New Economic Geography". KIER Working Paper 604. Kyoto University, Institute of Economic Research. 
Harvey, David. 2009. "Reshaping Economic Geography: The World Development 2009”. Development and Change 40(6):12691277.

Krugman, Paul. 2001. Geography and Trade, London Universitas Press.

Schmutzler, Armin. 1999. "The New Economic Geography". Journal of Economic Surveys 13:355-37.
Wood, Ellen Meiksins. 1994. "From Opportunity to Imperative: The History of the Market". Monthly Review 46(3). 2002. The Origin of Capitalism: A Longer View. (New York: Verso).

World Bank. 2009. World Bank Report: World: "Reshaping Economic Geography". Washington: 2009. 
